\title{
Student perspectives on intercultural learning from an online teacher education partnership
}

\section{Shannon Sauro ${ }^{1}$}

Abstract

$\mathrm{T}$ his study reports on intercultural learning during telecollaboration from the perspective of student participants in a five-country online teacher education partnership. The student perspectives reported here were drawn from one intact class in the partnership, five students who completed this partnership as part of a sociolinguistics course in a secondary school English teacher education program in Sweden. Offline, the telecollaboration served as a discussion point for course themes and as data for a study on a sociolinguistic topic carried out by each student. Findings revealed intercultural learning occurred in three situations: as a result of in-class conflict during discussion of the telecollaboration, through analysis of interactional styles found in the online discussion posts for the sociolinguistics study, and through online discussion with peers in other countries regarding educational practices.

Keywords: teacher education, sociolinguistics, telecollaboration, intercultural learning.

1. Malmö University, Malmö, Sweden; shannon.sauro@mah.se

How to cite this chapter: Sauro, S. (2016). Student perspectives on intercultural learning from an online teacher education partnership. In S. Jager, M. Kurek \& B. O'Rourke (Eds), New directions in telecollaborative research and practice: selected papers from the second conference on telecollaboration in higher education (pp. 83-88). Research-publishing.net. https://doi.org/10.14705/rpnet.2016.telecollab2016.493 


\section{Introduction}

Telecollaboration has an established history in university foreign language education extending over at least 20 years (O'Dowd, 2016). As is the case with many established language education practices, the effectiveness of telecollaboration to support language and intercultural learning has been the object of both investigation and scrutiny. A recent critique by Liddicoat and Scarino (2013) questions the degree to which the online interactions and tasks used in well-cited studies of telecollaboration truly supported intercultural learning. Specifically, they identify limitations in the online tasks which they defined as cultural tasks, "tasks that focused on factual information" and not intercultural tasks, which "involved learners moving between cultures and reflecting on their own cultural positioning" (Liddicoat \& Scarino, 2013, p. 117). As a result, they argue, intercultural learning did not occur automatically out of the online engagement.

O'Dowd (2016), however, points to a growing consensus in the telecollaboration literature which does not assume that intercultural learning occurs as a direct outcome of online interaction. One example can be found in Belz's (2007) discussion of in-class or reflective activities which allow learners to explore what Agar (1994) labels rich points, or points of contact between culturally situated ways of thinking which may result in misunderstanding or tension, that occurred during or around the online interaction.

Telecollaboration is more than a tool for language learning and also represents a means of bringing together distantly located future professionals whose 21 st century job demands may benefit from discussion and problem-solving with experts and peers in other contexts. Such was the motivation behind the teacher education partnership, Innovations in Foreign Language Education, which brought together language teacher education students in five countries (Canada, Israel, Spain, South Korea and Sweden). This partnership was organized into five modules, each tied to a technology-enhanced theme within language teaching (i.e. flipped classroom, telecollaboration, fandom tasks, social presence online, multimedia materials) and modeled upon the 
Sharing Perspectives (2015) model of exchange. Each module incorporated a video lecture, related readings and questions organized and moderated by a different expert, which were viewed, read and discussed by participants in five different multicultural groups. While the emphasis of a such a partnership was not on intercultural learning, the international and multicultural nature of the groupings and the participants potentially provided opportunities for Agar's (1994) rich points to occur around the use of technology in the participants' educational contexts.

Accordingly, this study explores if and when intercultural learning occurred for members of one of the partner classes in this online teacher education partnership.

\section{Methodology}

The student perspectives from this partnership were drawn from the partner class in Sweden and included all five students, four men and one woman, enrolled in the course. All were in their fifth and final year of a teacher education program preparing them to become secondary school English teachers. The telecollaboration itself was embedded in a sociolinguistics course, with each online module serving as a discussion point for course themes (i.e. language socialization, language ideologies, multimodal literacy, language and ethnicity, gender identities) and as data for a study on a sociolinguistic topic that each student was required to complete (see Sauro, 2016).

Student perspectives were elicited through a semi-structured interview held at the end of the course using a romantic approach "in which the interviewer strives to develop rapport with the interviewees in an effort to generate authentic, indepth dialog that focuses on participants' meanings" (Roulston, 2011, p. 78). This was augmented by tape analysis (Dörnyei, 2007) of audio recordings of the five one hour in-class discussions of each telecollaboration module, as well as analysis of the students' discussion board posts and the students' completed sociolinguistic studies. 


\section{Results and discussion}

Participants identified three situations where intercultural learning occurred: conflicts that arose during in-class discussion of the telecollaboration, analysis of discussion board posts for the sociolinguistics study, and during the online interaction. Each is illustrated in a vignette below.

\subsection{Conflict during in-class discussion}

Students identified rich points that resulted in conflict during weekly in-class discussion of the telecollaboration. One in particular concerned a disagreement over the interpretation of an Israel-based U.S. student's post regarding the need to carefully select books of fiction for her future students that would not run afoul of parental disapproval. In class, a conflict arose between Sam, who was dismayed by what he read as unprofessional acquiescence to parental interference, and Andy, who drew upon a gap year spent in the United States to interpret the post as an ironic critique of U.S. politics. Sam, however, drew upon his extensive experience in international online chat communities like Reddit, where irony and sarcasm are indexed through emoticons or other textual markers (e.g. /s to denote sarcasm) to reject Andy's interpretation.

Although neither persuaded the other to change their stance, the disagreement led Sam to observe that "even though we're both Swedes, me and Andy think very different from each other. Culture is as much group as it is individual. You can belong to a lot of different cultures and even though you belong to the same, the others you belong to will color your views so much that it's still not translated perfectly between each other".

\subsection{The sociolinguistic study}

Students also pointed to analysis of the discussion board postings for their sociolinguistics studies as another site of intercultural learning. Regina, who researched addressivity differences among the members of her online discussion 
group found that "when we did the research on the Schoology posts [the online platform], I got very aware of how I wrote my own posts".

In particular, a topic raised in the first class meeting regarding Swedish tendency to avoid conflict was revisited in Regina's analysis. She observed how her conflict avoidance strategies in online discussion limited the type of answers she was able to elicit from her peers, and subsequently her level of engagement in the telecollaboration compared to some of her peers: "I realize that I maybe was a bit scared of conflict and I should have just asked more questions or been a bit more pushed towards having an answer".

\subsection{Online interaction}

Finally, participants identified the online interaction during the telecollaboration as another source of intercultural learning, specifically discussions of educational practices. For Andy, this led to an awareness that what he had previously assumed to be a uniquely Swedish crisis in education was actually a common issue: "There seems to be this shared experience of public educators working in slightly underfunded schools and wanting to do all this stuff, but there just isn't money... And for a long time, I genuinely thought that was just something Swedish".

\section{Conclusion}

From the perspectives of students in this online teacher education partnership, intercultural learning, in other words, movement between different cultural viewpoints and reflection upon their own culture, occurred in three different situations. The first was as a result of conflict that arose during in-class discussion of the discussion board postings. The second was as a result of analyzing their own and others' interactional strategies in the discussion posts for their sociolinguistic studies. The third was during the online interaction itself and specifically during discussion of educational practices. Taken together, these 
reflect O'Dowd's (2016) argument that such learning occurs not necessarily as a direct result of online discussion but rather out of scaffolded offline discussion or structured reflection activities.

\section{References}

Agar, M. (1994). Language shock: understanding the culture of conversation. New York: William Morrow.

Belz, J. A. (2007). The development of intercultural communicative competence in telecollaborative partnerships. In R. O'Dowd (Ed.), Online intercultural exchange (pp. 127-166). Clevedon, UK: Multilingual Matters.

Dörnyei, Z. (2007). Research methods in applied linguistics. Oxford: Oxford University Press.

Liddicoat, A. J., \& Scarino, A. (2013). Intercultural language teaching and learning. Malden, MA: Wiley-Blackwell. http://dx.doi.org/10.1002/9781118482070

O'Dowd, R. (2016). Learning from the past and looking to the future of online intercultural exchange. In R. O’Dowd \& T. Lewis (Eds.), Online intercultural exchange: policy, pedagogy, practice (pp. 273-293). New York: Routledge.

Roulston, K. (2011). Interview 'problems' as topics for analysis. Applied Linguistics, 32(1), 77-94. http://dx.doi.org/10.1093/applin/amq036

Sauro, S. (2016). Sociolinguistics popular science piece instructions. https://www.academia. edu/25685629/Sociolinguistics_Popular_Scicence_Piece_Instructions

Sharing Perspectives. (2015). Sharing perspectives foundation. http://www.sharingperspectives foundation.com/ 


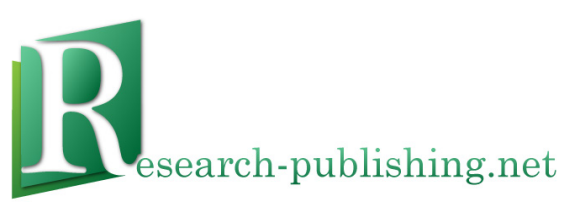

Published by Research-publishing.net, not-for-profit association Dublin, Ireland; Voillans, France, info@research-publishing.net

(C) 2016 by Editors (collective work)

(C) 2016 by Authors (individual work)

New directions in telecollaborative research and practice: selected papers from the second conference on telecollaboration in higher education

Edited by Sake Jager, Malgorzata Kurek, and Breffni O'Rourke

Rights: All articles in this collection are published under the Attribution-NonCommercial -NoDerivatives 4.0 International (CC BY-NC-ND 4.0) licence. Under this licence, the contents are freely available online as PDF files (https://doi.org/10.14705/rpnet.2016.telecollab2016.9781908416414) for anybody to read, download, copy, and redistribute provided that the author(s), editorial team, and publisher are properly cited. Commercial use and derivative works are, however, not permitted.

\section{(@) $\Theta \Theta \Theta$}

Disclaimer: Research-publishing.net does not take any responsibility for the content of the pages written by the authors of this book. The authors have recognised that the work described was not published before, or that it was not under consideration for publication elsewhere. While the information in this book are believed to be true and accurate on the date of its going to press, neither the editorial team, nor the publisher can accept any legal responsibility for any errors or omissions that may be made. The publisher makes no warranty, expressed or implied, with respect to the material contained herein. While Research-publishing.net is committed to publishing works of integrity, the words are the authors' alone.

Trademark notice: product or corporate names may be trademarks or registered trademarks, and are used only for identification and explanation without intent to infringe.

Copyrighted material: every effort has been made by the editorial team to trace copyright holders and to obtain their permission for the use of copyrighted material in this book. In the event of errors or omissions, please notify the publisher of any corrections that will need to be incorporated in future editions of this book.

Typeset by Research-publishing.net

Cover design and cover photos by (C) Raphaël Savina (raphael@savina.net)

UNICollab logo - Harriett Cornish, Graphic Designer, KMi, The Open University

ISBN13: 978-1-908416-40-7 (Paperback - Print on demand, black and white)

Print on demand technology is a high-quality, innovative and ecological printing method; with which the book is never 'out of stock' or 'out of print'.

ISBN13: 978-1-908416-41-4 (Ebook, PDF, colour)

ISBN13: 978-1-908416-42-1 (Ebook, EPUB, colour)

Legal deposit, Ireland: The National Library of Ireland, The Library of Trinity College, The Library of the University of Limerick, The Library of Dublin City University, The Library of NUI Cork, The Library of NUI Maynooth, The Library of University College Dublin, The Library of NUI Galway.

Legal deposit, United Kingdom: The British Library.

British Library Cataloguing-in-Publication Data.

A cataloguing record for this book is available from the British Library.

Legal deposit, France: Bibliothèque Nationale de France - Dépôt légal: novembre 2016. 